COMMUNICATIONS IN SOIL SCIENCE AND PLANT ANALYSIS

Vol. 34, Nos. 5 \& 6, pp. 801-814, 2003

\title{
Peanut Yield Response to Poultry Litter and Municipal Sludge Application
}

\author{
Kipling S. Balkcom, ${ }^{1}$ James F. Adams, ${ }^{2, *}$ \\ and Dallas L. Hartzog ${ }^{2}$ \\ ${ }^{1}$ National Peanut Research Laboratory, Dawson, Georgia, USA \\ ${ }^{2}$ Agronomy and Soils Department, Auburn University, Auburn, \\ Alabama, USA
}

\begin{abstract}
The use of poultry litter and sewage sludge as a nutrient source continues to increase. The purpose of this study was to evaluate the use of these organic by-products as a source of nutrients for peanut (Arachis hypogaea L.) production. From 1995 to 1998 poultry litter was applied on 13 on-farm sites and composted municipal sludge was used in three of these on-farm experiments. Fertilizer was also applied in all experiments. Rates of poultry litter ranged from 1.9 to $7.2 \mathrm{Mgha}^{-1}$. Composted sewage sludge rate was $2.0,4.0$, and $8.1 \mathrm{Mg} \mathrm{ha}^{-1}$. Commercial fertilizer was mixed and applied mixed together at 180,40 , and $111 \mathrm{~kg} \mathrm{ha}^{-1}$ for nitrogen $(\mathrm{N}), \mathrm{P}_{2} \mathrm{O}_{5}$ and $\mathrm{K}_{2} \mathrm{O}$, respectively. Phosphorus $(\mathrm{P})$ and potassium (K) were also supplied separately at a rate of 40 and $111 \mathrm{~kg} \mathrm{ha}^{-1}$, respectively. Seven of 13 sites had increased yield as a result of poultry
\end{abstract}

*Correspondence: James F. Adams, Agronomy and Soils Department, Auburn University, 201 Funchess Hall, Auburn, AL 36849, USA; E-mail: jadams@ acesag.auburn.edu.

\section{1}

DOI: 10.1081/CSS-120018976

0010-3624 (Print); 1532-2416 (Online)

Copyright (C) 2003 by Marcel Dekker, Inc.

www.dekker.com 
litter. Fertilizer increased yield in only two experiments. Sludge increased yield in only one experiment and only the highest rate. At one site, poultry litter gave a greater yield than fertilizer when both increased yield above the control. Treatments did not influence total sound mature kernels percentage (TSMK).

Key Words: $\mathrm{Ca} ; \mathrm{Cu}$; P; K; TSMK.

\section{INTRODUCTION}

Agriculture has long recognized the benefits of waste materials as a nutrient source and their ability to improve the physical and chemical properties of soils. Land application of poultry litter and composted sewage sludge provides an opportunity for recycling of nutrients and reducing the amount of litter or sludge disposed in landfills.

The southern states of Alabama, Florida, and Georgia produced over 2.1 billion broilers in $1999 .{ }^{[1]}$ This would equate to about 2.3 million tons of broiler litter produced annually. The peanut growing counties of Alabama, Georgia, and Florida have substantial broiler production and it is continuing to increase. This increase means that more and more peanut land will receive poultry litter. The litter is a mixture of the poultry manure, bedding material, water, and wasted feed. Analysis of litter collected in Alabama in the mid 1980s through 1993 indicates that poultry litter approximates 3-2-2 fertilizer ${ }^{[2]}$ Secondary plant nutrients [calcium $(\mathrm{Ca})$, magnesium $(\mathrm{Mg})$, and sulfur $(\mathrm{S})$ ] and micronutrients [copper $(\mathrm{Cu})$, iron $(\mathrm{Fe})$, manganese $(\mathrm{Mn})$, and zinc $(\mathrm{Zn})]$ are also present in litter. Field studies, conducted in Alabama, have shown beneficial effects from poultry litter applications on corn (Zea mays L.), wheat (Triticum aestivum L.) and forages mainly due to $\mathrm{N}$ content of the poultry litter. ${ }^{[3]}$ Cotton has also benefited from poultry litter application. ${ }^{[4]}$

Sewage sludge is a by-product of our society with municipalities generating over 4.5 million $\mathrm{Mg}$ of sludge ${ }^{[5]}$ in the United States annually. A survey conducted in 1995 in showed that approximately 41 thousand $\mathrm{Mg}$ of sludge are produced annually in Alabama. ${ }^{[6]}$

Municipal sludges contain essential elements such as N, P, K, Ca, and $\mathrm{Mg}{ }^{[7]}$ Micronutrients such as $\mathrm{Cu}, \mathrm{Fe}$, and $\mathrm{Zn}$ are considered heavy metals and are often associated with municipal sludges due to industrial wastes. ${ }^{[8]}$

The wastes are not free from disadvantages and require intensive management. To prevent potential toxicities problems $\mathrm{pH}$ of the soil should be maintained around 6.5 for sludge applications, ${ }^{[9]}$ because heavy metals can become more soluble in the low $\mathrm{pH}$ range. Continued application of these 
materials with no management could result in environmental problems that could take a very long time to correct.

Alabama alone produces a tremendous amount of both materials. Presently, no published data exists which describe the response of peanuts to litter or sludge and both of these products are readily available in the peanut producing region of the state. The objective of this study was to determine if land application of these organic amendments could be beneficial or harmful on yield and total sound mature kernel percentage (TSMK) in peanut production.

\section{MATERIALS AND METHODS}

Thirteen on-farm experiments were conducted from 1993 to 1998 in Barbour and Henry counties located in Alabama, but none repeated in the same field. Climates at all sites are classified as subtropical with no dry season and a mean annual rainfall of $127 \mathrm{~cm}$, and mean annual temperature of $19^{\circ} \mathrm{C}^{[10]}$ Treatment which consisted of rates of poultry litter, rates of composted sewage sludge and inorganic fertilizers were arranged in randomized complete block designs with 4 to 5 replications. Plots were 5.5 by $15.2 \mathrm{~m}$ consisting of six rows with only the middle two rows harvested. Poultry litter was stored dry in a barn at the Wiregrass Research and Extension Center Rates and this was the only source of poultry litter that was used for all experiments. Composted sewage sludge was stored in plastic bags at the same location. Percent moisture was determined prior to each experiment. Rates of poultry litter were $1.9,3.8$, and $7.6 \mathrm{Mg} \mathrm{ha}^{-1}$ and composted sewage sludge $2.0,4.0$, and $8 \mathrm{Mg} \mathrm{ha}^{-1}$ on a dry weight basis. There were two inorganic fertilizer treatments which were 1) 180,27 , and $111 \mathrm{~kg} \mathrm{ha}^{-1}$, of $\mathrm{N}, \mathrm{P}$, and $\mathrm{K}$, respectively with $1.8,1.6 \mathrm{~kg} \mathrm{ha}^{-1}$ and $27 \mathrm{~g} \mathrm{ha}^{-1}$ of $\mathrm{Cu}, \mathrm{Zn}$, and $\mathrm{Mo}$, respectively; and 2) then at some sites $\mathrm{P}$ and $\mathrm{K}$ were applied as separate treatments with a third treatment of a complete mix of $\mathrm{N}-\mathrm{P}-\mathrm{K}$ as previously mentioned. Nitrogen and micronutrients rates were based on the $3.8 \mathrm{Mg} \mathrm{ha}^{-1}$ poultry litter application while $\mathrm{P}$ and $\mathrm{K}$ were applied at recommended rates when a soil test has a low rating according to Auburn University Soil-Test Laboratory. This resulted in a $\mathrm{P}$ application of $27 \mathrm{~kg} \mathrm{ha}^{-1}$ from fertilizer compared to $74 \mathrm{~kg} \mathrm{ha}^{-1}$ from the $3.8 \mathrm{Mg} \mathrm{ha}^{-1}$ poultry litter rate. Potassium rates were similar with $111 \mathrm{~kg} \mathrm{ha}^{-1}$ from fertilizer and $112 \mathrm{~kg} \mathrm{ha}^{-1}$ supplied by the $3.8 \mathrm{Mgha}^{-1}$ poultry litter rate. Because of limited space not all treatments were not used at all sites and specific ones used for each site are listed in Table 1. A control treatment was included at all locations. All materials were applied by hand approximately one month before planting and 
Table 1. Treatments applied to 13 on-farm experiments in Alabama conducted from 1993 to 1998.

\begin{tabular}{|c|c|c|c|c|c|c|c|c|c|}
\hline \multirow{2}{*}{$\frac{\text { Site }}{1}$} & \multicolumn{3}{|c|}{$\begin{array}{l}\text { Poultry litter } \\
\left(\mathrm{Mg} \mathrm{ha}^{-1}\right)\end{array}$} & \multicolumn{3}{|c|}{$\begin{array}{l}\text { Sewage sludge } \\
\left(\mathrm{Mg} \mathrm{ha}^{-1}\right)\end{array}$} & \multicolumn{3}{|c|}{ Fertilizer $\left(\mathrm{kg} \mathrm{ha}^{-1}\right)$} \\
\hline & 1.9 & 3.8 & 7.6 & & & & $\mathrm{~N}-\mathrm{P}-\mathrm{K}$ & & \\
\hline 2 & 1.9 & 3.8 & 7.6 & & & & $\mathrm{~N}-\mathrm{P}-\mathrm{K}$ & & \\
\hline 3 & 1.9 & 3.8 & 7.6 & & & & $\mathrm{~N}-\mathrm{P}-\mathrm{K}$ & & \\
\hline 4 & 1.9 & 3.8 & 7.6 & & & & $\mathrm{~N}-\mathrm{P}-\mathrm{K}$ & & \\
\hline 5 & & 3.8 & 7.6 & & & & $\mathrm{~N}-\mathrm{P}-\mathrm{K}$ & & \\
\hline 6 & & 3.8 & & & & & $\mathrm{~N}-\mathrm{P}-\mathrm{K}$ & $\mathrm{K}$ & $\mathrm{P}$ \\
\hline 7 & & 3.8 & & & & & $\mathrm{~N}-\mathrm{P}-\mathrm{K}$ & $\mathrm{K}$ & $\mathrm{P}$ \\
\hline 8 & & 3.8 & 7.6 & 2 & 4 & 8 & $\mathrm{~N}-\mathrm{P}-\mathrm{K}$ & $\mathrm{K}$ & $\mathrm{P}$ \\
\hline 9 & & 3.8 & 7.6 & 2 & 4 & 8 & $\mathrm{~N}-\mathrm{P}-\mathrm{K}$ & $\mathrm{K}$ & $\mathrm{P}$ \\
\hline 10 & & 3.8 & 7.6 & 2 & 4 & 8 & $\mathrm{~N}-\mathrm{P}-\mathrm{K}$ & $\mathrm{K}$ & $\mathrm{P}$ \\
\hline 11 & & 3.8 & & 2 & & & & $\mathrm{~K}$ & $\mathrm{P}$ \\
\hline 12 & & 3.8 & & 2 & & & & $\mathrm{~K}$ & $\mathrm{P}$ \\
\hline 13 & & 3.8 & & 2 & & & & $\mathrm{~K}$ & $\mathrm{P}$ \\
\hline
\end{tabular}

${ }^{a}$ Organic amendments applied on dry weight basis.

incorporated into the soil. Farmers were responsible for all cultural practices except treatment applications and harvesting.

Classification of soils was made on-site and is listed in Table 2. Initial soil test values for $\mathrm{Ca}, \mathrm{K}, \mathrm{Mg}$, and $\mathrm{P}$ were measured using the Mehlich $1^{[11]}$ extract and soil $\mathrm{pH}$ was determined with a 1:1 soil water mixture. Litter and sludge amendments were dried at $50^{\circ} \mathrm{C}$ for $48 \mathrm{hrs}$., ground in a Retch high speed grinder and analyzed for selected properties (Table 3). Total $\mathrm{C}$ and $\mathrm{N}$ were determined using a LECO-CHN 600 (LECO Corp., St. Joseph, MI). A 0.5-g sample was dry ashed in a muffle furnace at $450^{\circ} \mathrm{C}$ for at least $4 \mathrm{hrs}$ to determine percent ash. Another 0.5-g sample was digested in a 70:30 mixture of nitric and perchloric acid overnight ${ }^{[12]}$ and analyzed for $\mathrm{P}, \mathrm{K}, \mathrm{Ca}, \mathrm{Mg}, \mathrm{Cu}, \mathrm{Mn}$, lead $(\mathrm{Pb})$, and Zn, using an inductively coupled argon plasma spectrophotometer (ICAP) (Jarrel-Ash Division/Fisher Scientific Co., Waltham, MA).

Peanuts were harvested from the center two rows of each plot to determine yield and percentage of total sound mature kernels (TSMK). Yield was determined by weighing freshly harvested nuts in the field and adjusted for moisture content. Subsamples were taken, dried, shelled and graded for TSMKs.

Analysis of variance was performed for each experiment using the General Linear Model procedures provided by the Statistical Analysis 
Table 2. Classification of soils and selected soil chemical properties of 13 on-farm experiments in Alabama conducted in 1993 and 1998 .

\begin{tabular}{|c|c|c|c|c|c|c|c|}
\hline \multirow[b]{2}{*}{ Site } & \multirow[b]{2}{*}{ Soil series } & \multirow[b]{2}{*}{ Family } & \multirow[b]{2}{*}{$\mathrm{pH}$} & \multicolumn{4}{|c|}{ Mehlich 1 extractable } \\
\hline & & & & $\begin{array}{c}\mathrm{Ca} \\
\left(\mathrm{mg} \mathrm{kg}^{-1}\right)\end{array}$ & $\begin{array}{c}\mathrm{P} \\
\left(\mathrm{mg} \mathrm{kg}^{-1}\right)\end{array}$ & $\begin{array}{c}\mathrm{K} \\
\left(\mathrm{mg} \mathrm{kg}^{-1}\right)\end{array}$ & $\begin{array}{c}\mathrm{Mg} \\
\left(\mathrm{mg} \mathrm{kg}^{-1}\right)\end{array}$ \\
\hline 1 & Fuquay ls & $\begin{array}{l}\text { Loamy, kaolinitic, thermic Arenic } \\
\text { Plinthic } \\
\text { Kandiudults }\end{array}$ & 5.9 & $287(\mathrm{H})$ & $25(\mathrm{H})$ & $12(\mathrm{~L})$ & $13(\mathrm{H})$ \\
\hline 2 & Troup ls & $\begin{array}{l}\text { Loamy, siliceous, thermic Grossarenic, } \\
\text { Paleudult }\end{array}$ & 5.4 & $112(\mathrm{~L})$ & $15(\mathrm{H})$ & $11(\mathrm{~L})$ & $17(\mathrm{H})$ \\
\hline 3 & Lucy ls & $\begin{array}{l}\text { Loamy, siliceous, thermic, arenic Kan- } \\
\text { diudult }\end{array}$ & 7.0 & $425(\mathrm{H})$ & $12(\mathrm{H})$ & $19(\mathrm{M})$ & $25(\mathrm{H})$ \\
\hline 4 & Dothan sl & $\begin{array}{l}\text { Fine-loamy, kaolinitic, thermic Plinthic } \\
\text { Kandiudults }\end{array}$ & 5.6 & $217(\mathrm{H})$ & $46(\mathrm{VH})$ & $25(\mathrm{H})$ & $20(\mathrm{H})$ \\
\hline 5 & Bonifay ls & $\begin{array}{l}\text { Loamy, siliceous, thermic, Grossarenic } \\
\text { Plinthic Paleudult }\end{array}$ & 4.9 & $58(\mathrm{~L})$ & $3(\mathrm{~L})$ & $13(\mathrm{~L})$ & $6(\mathrm{~L})$ \\
\hline 6 & Dothan sl & $\begin{array}{l}\text { Fine-loamy, kaolinitic, thermic Plinthic } \\
\text { Kandiudults }\end{array}$ & 6.3 & $364(\mathrm{H})$ & $21(\mathrm{H})$ & $20(\mathrm{M})$ & $21(\mathrm{H})$ \\
\hline 7 & Dothan sl & $\begin{array}{l}\text { Fine-loamy, kaolinitic, thermic Plinthic } \\
\text { Kandiudults }\end{array}$ & 6.9 & $617(\mathrm{H})$ & $22(\mathrm{H})$ & $14(\mathrm{~L})$ & $13(\mathrm{H})$ \\
\hline 8 & Troup ls & $\begin{array}{l}\text { Loamy, siliceous, thermic Grossarenic, } \\
\text { Paleudult }\end{array}$ & 6.2 & $63(\mathrm{~L})^{\mathrm{a}}$ & $13(\mathrm{H})$ & $18(\mathrm{M})$ & $9(\mathrm{~L})$ \\
\hline
\end{tabular}


Table 2. Continued.

\begin{tabular}{|c|c|c|c|c|c|c|c|}
\hline \multirow[b]{2}{*}{ Site } & \multirow[b]{2}{*}{ Soil series } & \multirow[b]{2}{*}{ Family } & \multirow[b]{2}{*}{$\mathrm{pH}$} & \multicolumn{4}{|c|}{ Mehlich 1 extractable } \\
\hline & & & & $\begin{array}{c}\mathrm{Ca} \\
\left(\mathrm{mg} \mathrm{kg}^{-1}\right)\end{array}$ & $\begin{array}{c}\mathrm{P} \\
\left(\mathrm{mg} \mathrm{kg}^{-1}\right)\end{array}$ & $\begin{array}{c}\mathrm{K} \\
\left(\mathrm{mg} \mathrm{kg}^{-1}\right)\end{array}$ & $\begin{array}{c}\mathrm{Mg} \\
\left(\mathrm{mg} \mathrm{kg}^{-1}\right)\end{array}$ \\
\hline 9 & Bonifay ls & $\begin{array}{l}\text { Loamy, siliceous, thermic, Grossarenic } \\
\text { Plinthic Paleudult }\end{array}$ & 6.5 & $440(\mathrm{H})$ & $7(\mathrm{M})$ & $25(\mathrm{H})$ & $19(\mathrm{H})$ \\
\hline 10 & Bonifay ls & $\begin{array}{l}\text { Loamy, siliceous, thermic, Grossarenic } \\
\text { Plinthic Paleudult }\end{array}$ & 6.7 & $337(\mathrm{H})$ & $2(\mathrm{VL})$ & $4(\mathrm{VL})$ & 7 (L) \\
\hline 11 & Orangeburg sl & $\begin{array}{l}\text { Fine-loamy, kaolinitic, thermic Typic } \\
\text { Kandiudults }\end{array}$ & 5.7 & $121(\mathrm{M})$ & $11(\mathrm{H})$ & $20(\mathrm{M})$ & $13(\mathrm{H})$ \\
\hline 12 & Lucy ls & $\begin{array}{l}\text { Loamy, siliceous, thermic, arenic } \\
\text { Kandiudult }\end{array}$ & 6.4 & $241(\mathrm{H})$ & $10(\mathrm{H})$ & $8(\mathrm{VL})$ & $30(\mathrm{H})$ \\
\hline 13 & Troup ls & $\begin{array}{l}\text { Loamy, siliceous, thermic Grossarenic, } \\
\text { Paleudult }\end{array}$ & 6.3 & $245(\mathrm{H})$ & $19(\mathrm{H})$ & $10(\mathrm{VL})$ & $19(\mathrm{H})$ \\
\hline
\end{tabular}

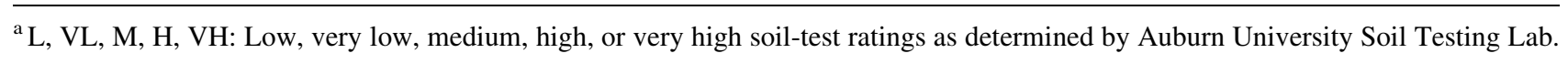


Table 3. Analysis of organic amendments on dry weight basis.

\begin{tabular}{|c|c|c|}
\hline Element & Poultry & Sludge \\
\hline & \multicolumn{2}{|c|}{$(\%)$} \\
\hline $\mathrm{N}$ & 4.47 & 1.88 \\
\hline $\mathrm{P}$ & 1.95 & 0.62 \\
\hline $\mathrm{K}$ & 2.95 & 0.17 \\
\hline $\mathrm{Ca}$ & 2.89 & 0.88 \\
\hline $\mathrm{Mg}$ & 0.53 & 0.11 \\
\hline Ash & 20.3 & 7.1 \\
\hline $\mathrm{H}_{2} \mathrm{O}$ & 15.7 & 55.0 \\
\hline Carbon & 29.0 & 43.4 \\
\hline \multirow[t]{2}{*}{$\mathrm{C}: \mathrm{N}$ ratio } & 6.5 & 23.1 \\
\hline & \multicolumn{2}{|c|}{$\left(\mathrm{mg} \mathrm{kg}^{-1}\right)$} \\
\hline $\mathrm{Cu}$ & 482 & 109.2 \\
\hline $\mathrm{Pb}$ & 10.2 & 24.8 \\
\hline $\mathrm{Mn}$ & 532.6 & 420.4 \\
\hline Mo & 7.2 & 12.3 \\
\hline $\mathrm{Zn}$ & 421.3 & 845.2 \\
\hline
\end{tabular}

System $^{[13]}$ to determine if there were significant treatment effects. Treatment means from each experiment were separated by Fishers protected least significant difference method (LSD) if that site was shown to have significant treatment effect at the $10 \%$ level from the analysis of variance.

\section{RESULTS AND DISCUSSION}

\section{Yield}

Yield increased at seven of 13 sites (Table 4) where poultry litter was applied and fertilizer increased yield significantly at 2 of 13 experiments. Site 1 had increased yield at the lowest rate $\left(1.9 \mathrm{Mg} \mathrm{ha}^{-1}\right)$ while yields from the fertilizer and other higher poultry litter rates did not differ from the control at the $10 \%$ probability level. Soil test $\mathrm{Ca}, \mathrm{P}$, and $\mathrm{Mg}$ were rated "high" while $\mathrm{K}$ was rated "low." Increased yield may have been due to $\mathrm{K}$ addition from the poultry litter. Soil-test calibration data for this site indicates that soil $\mathrm{K}$ was borderline sufficient ${ }^{[14]}$ and there may well have been a response to added 
Table 4. Litter, sludge, and fertilizer application effect on yield from 13 on-farm experiments conducted in Alabama from 1993 and 1998.

\begin{tabular}{|c|c|c|c|c|c|c|c|c|c|c|c|}
\hline \multirow[b]{2}{*}{ Site } & \multirow{2}{*}{$\begin{array}{c}\text { Control } \\
\left(\text { yield, } \mathrm{kg} \mathrm{ha}^{-1} \text { ) }\right.\end{array}$} & \multicolumn{3}{|c|}{$\begin{array}{l}\text { Poultry litter }{ }^{\mathrm{a}} \text { (yield, } \\
\qquad \mathrm{kg} \mathrm{ha}^{-1} \text { ) }\end{array}$} & \multicolumn{3}{|c|}{ Sludge $^{\mathrm{b}}$ (yield, $\mathrm{kg} \mathrm{ha}^{-1}$ ) } & \multicolumn{3}{|c|}{ Fert. (yield, $\mathrm{kg} \mathrm{ha}^{-1}$ ) } & \multirow{2}{*}{$\begin{array}{c}\mathrm{LSD}^{\mathrm{c}} \\
\left(\text { yield, } \mathrm{kg} \mathrm{ha}^{-1} \text { ) }\right.\end{array}$} \\
\hline & & 1.9 & 3.8 & 7.6 & 2.0 & 4.0 & 8.1 & $\mathrm{~N}-\mathrm{P}-\mathrm{K}$ & $\mathrm{K}$ & $P$ & \\
\hline 1 & 2520 & 3160 & 2970 & 2880 & & & & 2810 & & & 510 \\
\hline 2 & 4350 & 4370 & 4380 & 4460 & & & & 4130 & & & NS \\
\hline 3 & 4350 & 4650 & 4480 & 4650 & & & & 4290 & & & NS \\
\hline 4 & 4270 & 4450 & 4520 & 4410 & & & & 4290 & & & NS \\
\hline 5 & 1930 & & 2900 & 3120 & & & & 2210 & & & 420 \\
\hline 6 & 4680 & & 5240 & & & & & 4620 & 4740 & 4300 & 520 \\
\hline 7 & 4440 & & 5030 & & & & & 4350 & 4560 & 4000 & 620 \\
\hline 8 & 2500 & & 3410 & 3470 & 2140 & 3240 & 2660 & 2580 & 2560 & 2910 & 870 \\
\hline 9 & 2740 & & 3210 & 3960 & 2800 & 2930 & 2920 & 3550 & 2570 & 2830 & 570 \\
\hline 10 & 2190 & & 3870 & 4980 & 2580 & 3100 & 3040 & 3660 & 2540 & 2710 & 680 \\
\hline 11 & 5300 & & 5180 & & 5440 & & & & 5160 & 5680 & NS \\
\hline 12 & 4730 & & 5640 & & 4850 & & & & 4640 & 4900 & 220 \\
\hline 13 & 4080 & & 4930 & & 3850 & & & & 4020 & 3620 & NS \\
\hline
\end{tabular}

a Poultry litter applied in $\mathrm{Mg} \mathrm{ha}^{-1}$.

${ }^{\mathrm{b}}$ Composted sludge applied in $\mathrm{Mg} \mathrm{ha}^{-1}$.

${ }^{\mathrm{c}} \mathrm{LSD}$ at $10 \%$ level from control. 
K. Yield at sites 2, 3, and 4 did not vary among treatments. Soil test data at these sites indicate that fertility levels were borderline or adequate. ${ }^{[15]}$

Yield at site 5 was increased with both rates of poultry litter, but fertilizer did not increase yield significantly. The yield increase may have been due to $\mathrm{Ca}$ in the litter. Soil test Ca was "low" $\left(58 \mathrm{mg} \mathrm{kg}^{-1}\right)$. Approximately 110 and $220 \mathrm{~kg}$ of $\mathrm{Caha}^{-1}$ was applied with the 3.8 and $7.6 \mathrm{Mg} \mathrm{ha}^{-1}$ litter rate, respectively. The Ca application would be equivalent to 480 and $960 \mathrm{~kg} \mathrm{ha}^{-1}$ of gypsum. Phosphorus and K soil-test was "low" as well but fertilizer application had no effect on yield. Poultry litter at the highest rate $\left(7.6 \mathrm{Mg} \mathrm{ha}^{-1}\right.$ ) resulted in increased yield of $1190 \mathrm{~kg} \mathrm{ha}^{-1}$ over the control.

Yield at sites 6, 7, and 8 were also increased with poultry litter, but not with fertilizer. The increased yield at sites 6 and 7 appear to be related to factors other than nutrients. Soil test K was low at site 6 but K did not increase yield. The primary reason for yield increase at site 8 was the same as for site 5 , initially inadequate soil $\mathrm{Ca}\left(63 \mathrm{mg} \mathrm{kg}^{-1}\right)$. Magnesium was also low and the low rate of litter at this site supplied $20 \mathrm{~kg} \mathrm{ha}^{-1}$ that may have provided adequate $\mathrm{Mg}$. Hartzog and Adams ${ }^{[16,17]}$ conducted five $\mathrm{Mg}$ fertilization experiments with the "low" soil test $\mathrm{Mg}$ ranging from 3.5 to $7.5 \mathrm{mg} \mathrm{kg}^{-1}$ with no yield increase when $\mathrm{Mg}$ was applied. Only one experiment in Alabama had increased yield due to $\mathrm{Mg}$ application. This experiment had a soil $\mathrm{Mg}$ of $3.5 \mathrm{mg} \mathrm{kg}^{-1}$. $^{[15]}$ Yield response to litter at sites 5, 8 and 10 may not have been due to added $\mathrm{Mg}$, even though their soil test ratings were low, the lowest soil $\mathrm{Mg}$ in these experiments was $6 \mathrm{mg} \mathrm{ha}^{-1}$, almost twice that found by Adams and Hartzog ${ }^{[15]}$ that was deficient.

Poultry litter increased yield at sites 9 and 10 and the complete fertilizer (NPK) also increased yield. Additionally, poultry litter had higher yields than those obtained with fertilizer application. The $\mathrm{P}$ and $\mathrm{K}$ treatments alone did not increase yield. Soil test reveal that soil test $\mathrm{P}$ for sites 9 and 10 were $7 \mathrm{mg} \mathrm{kg}^{-1}(\mathrm{M})$ and $2 \mathrm{mg} \mathrm{kg}^{-1}(\mathrm{VL})$, respectively. Potassium soil test were $25 \mathrm{mg} \mathrm{kg}^{-1}(\mathrm{H})$ and $4 \mathrm{mg} \mathrm{kg}^{-1}$ (VL) for sites 9 and 10 , respectively. These were the only two sites that had increased yield with fertilizer. Since the inorganic fertilizer without $\mathrm{N}$ did not increase yield, a synergistic effect of multiple nutrient application (NPK) may have been required for a yield response.

Litter increased yield at site 12 but not sites 11 and 13. Soil test K for site 12 was $8 \mathrm{mg} \mathrm{kg}^{-1}(\mathrm{VL})$. The increased yield may be the same as for sites 5,6 , 7, and 8 . Soil test $\mathrm{P}, \mathrm{K}$, and $\mathrm{Ca}$ at sites 11 and 13 were adequate which may account for no yield response.

Municipal sludge, applied at $2.0 \mathrm{Mgha}^{-1}$, did not result in a yield increase at any site. As the sludge rate was increased to 4.0 and $8.1 \mathrm{Mg} \mathrm{ha}^{-1}$, there was a yield increased at site 10 . The yield was less than that obtained 
with poultry litter. At this site $\mathrm{P}$ and $\mathrm{K}$ were "very low," 2 and $4 \mathrm{mg} \mathrm{kg}^{-1}$, respectively. The sludge supplied only 50 and $14 \mathrm{kgha}^{-1}$ of $\mathrm{P}$ and $\mathrm{K}$, respectively. This may explain the smaller increase in yield from sludge application as compared to poultry litter.

Commercial fertilizer was applied as $\mathrm{N}-\mathrm{P}-\mathrm{K}$ at 10 of the 13 sites and five of these sites had a separate $\mathrm{P}$ and $\mathrm{K}$ treatment as well. Yield response to fertilizer occurred at only two of 13 sites (sites 9 and 10). Only the complete fertilizer increased yield while $\mathrm{P}$ and $\mathrm{K}$ alone did not result in a significant increase in yield. Site 10 was very low in $\mathrm{P}$ and $\mathrm{K}$ and site 9 was medium in $\mathrm{P}$ and high in everything else. A lack of response at 2 sites (5 and 8) can be attributed to low soil $\mathrm{Ca}$ values and low $\mathrm{pH}$ (Table 2) that restricted yields when no Ca was applied. Hartzog and Adams ${ }^{[14]}$ found from $39 \mathrm{P}$ and $\mathrm{K}$ experiments that significant yield increases from $\mathrm{K}$ application only occurred when soil test $\mathrm{K}$ was less than $9 \mathrm{mg} \mathrm{kg}^{-1}$. Only two sites had soil test $\mathrm{K}$ levels that were lower (sites 10 and 12).

\section{TSMK}

Lower TSMKs were found in two of 13 experiments (Table 5) for poultry litter when compared to the control. At site 1 the highest rate of poultry litter decreased TSMK while at site 3 the decrease of TSMK was at the lowest rate of litter application. On the other hand, higher TSMKs were found at sites 9 and 12. There did not appear to be a trend in TSMKs and poultry litter application across all 13 experiments. Three sites had higher TSMKs with fertilizer, but only for the NPK treatment. No fertilizer treatment decreased TSMK. Composted sludge increased TSMK only at site 9 and at all rates of applied sludge. There were no decreases in TSMKs due to sludge application. There was no apparent trend in TSMKs for any of the treatments and no differences were expected due to the organic or inorganic amendments.

\section{Soil Phosphorus}

Phosphorus has recently received attention from researchers in terms of waste management. Alabama Department of Environmental Management (ADEM) monitors nutrient management plans for poultry waste disposal and their compliance. Soil test $\mathrm{P}$ was determined at harvest on 10 of 13 on-farm experiments (Table 6). Poultry litter increased soil P on 6 of the 10 sites sampled with the largest increase in soil with the high rate of poultry litter $\left(7.6 \mathrm{Mg} \mathrm{ha}^{-1}\right)$. The increase in soil $\mathrm{P}$ from poultry litter ranged from 52 to 
Table 5. Litter, sludge, and fertilizer application effect on TSMK from 13 on-farm experiments conducted in Alabama from 1993 and 1998.

\begin{tabular}{|c|c|c|c|c|c|c|c|c|c|c|c|}
\hline \multirow[b]{2}{*}{ Site } & \multirow{2}{*}{$\begin{array}{c}\text { Control } \\
(\mathrm{TSMKs}, \%)\end{array}$} & \multicolumn{3}{|c|}{$\begin{array}{l}\text { Poultry litter } \\
\text { (TSMKs, \%) }\end{array}$} & \multicolumn{3}{|c|}{$\begin{array}{c}\text { Sludge }^{\mathrm{b}} \\
\text { (TSMKs, \%) }\end{array}$} & \multicolumn{3}{|c|}{ Fert. (TSMKs, \%) } & \multirow{2}{*}{$\begin{array}{c}\mathrm{LSD}^{\mathrm{c}} \\
(\mathrm{TSMKs}, \%)\end{array}$} \\
\hline & & 1.9 & 3.8 & 7.6 & 2.0 & 4.0 & 8.1 & $\mathrm{~N}-\mathrm{P}-\mathrm{K}$ & K & $\mathrm{P}$ & \\
\hline 1 & 67 & 68 & 65 & 64 & & & & 68 & & & 2.7 \\
\hline 2 & 63 & 63 & 66 & 62 & & & & 65 & & & NS \\
\hline 3 & 73 & 71 & 74 & 75 & & & & 75 & & & 1.4 \\
\hline 4 & 76 & 75 & 77 & 77 & & & & 76 & & & NS \\
\hline 5 & 72 & & 73 & 73 & & & & 71 & & & NS \\
\hline 6 & 72 & & 73 & & & & & 74 & 74 & 73 & 1.5 \\
\hline 7 & 71 & & 72 & & & & & 69 & 72 & 72 & 2.2 \\
\hline 8 & 71 & & 72 & 71 & 71 & 73 & 71 & 69 & 69 & 72 & NS \\
\hline 9 & 72 & & 74 & 73 & 75 & 76 & 74 & 74 & 73 & 73 & 1.3 \\
\hline 10 & 72 & & 74 & 73 & 70 & 73 & 73 & 70 & 73 & 72 & NS \\
\hline 11 & 74 & & 72 & & 74 & & & & 74 & 75 & NS \\
\hline 12 & 71 & & 74 & & 74 & & & & 71 & 72 & 1.6 \\
\hline 13 & 67 & & 68 & & 68 & & & & 66 & 68 & NS \\
\hline
\end{tabular}

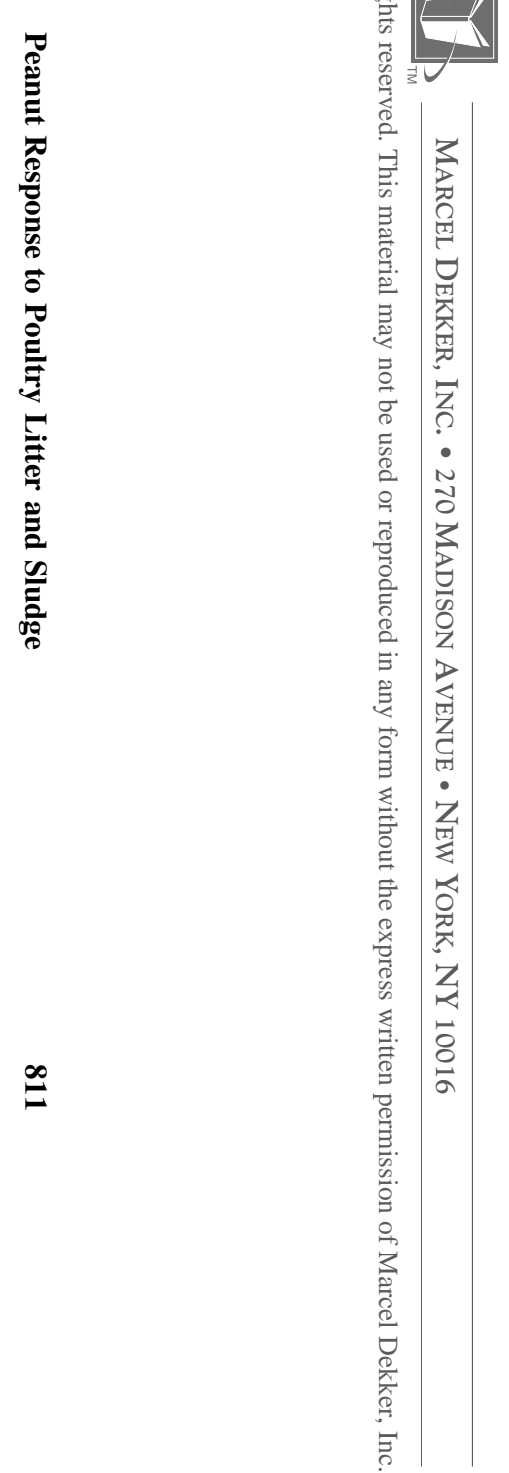

${ }^{\text {a }}$ Poultry litter applied in $\mathrm{Mg} \mathrm{ha}^{-1}$.

${ }^{\mathrm{b}}$ Composted sludge applied in $\mathrm{Mg} \mathrm{ha}^{-1}$.

${ }^{\mathrm{c}} \mathrm{LSD}$ at $10 \%$ level from control. 
Table 6. Soil test phosphorus concentration at harvest from poultry litter, municipal sludge, and fertilizer treatments from 10 of 13 on-farm experiments conducted in Alabama from 1993 to 1998.

\begin{tabular}{|c|c|c|c|c|c|c|c|c|c|c|c|}
\hline \multirow[b]{2}{*}{ Site } & \multirow{2}{*}{$\begin{array}{l}\text { Control (Phosphorus, } \\
\mathrm{mg} \mathrm{kg}^{-1} \text { ) }\end{array}$} & \multicolumn{3}{|c|}{$\begin{array}{c}\text { Poultry litter } \\
\text { (Phosphorus, } \\
\text { mg kg }^{-1} \text { ) }\end{array}$} & \multicolumn{3}{|c|}{$\begin{array}{c}\text { Sludge }^{\mathrm{b}} \\
\text { (Phosphorus, } \text { ( } \mathrm{mg} \mathrm{kg}^{-1} \text { ) }\end{array}$} & \multicolumn{3}{|c|}{$\begin{array}{l}\text { Fert. (Phosphorus, } \\
\mathrm{mg} \mathrm{kg}^{-1} \text { ) }\end{array}$} & \multirow{2}{*}{$\begin{array}{c}\text { LSD }^{\mathrm{c}} \\
\text { (Phosphorus, } \mathrm{mg} \mathrm{kg}^{-1} \text { ) }\end{array}$} \\
\hline & & 1.9 & 3.8 & 7.6 & 2.0 & 4.0 & 8.1 & $\mathrm{~N}-\mathrm{P}-\mathrm{K}$ & $\mathrm{K}$ & $\mathrm{P}$ & \\
\hline 1 & 25 & 26 & 27 & 25 & & & & 34 & & & 7 \\
\hline 2 & 15 & 20 & 21 & 26 & & & & 25 & & & 5 \\
\hline 3 & 12 & 12 & 13 & 13 & & & & 16 & & & 5 \\
\hline 4 & 46 & 42 & 45 & 45 & & & & 49 & & & 7 \\
\hline 5 & 3 & & 6 & 10 & & & & 7 & & & 3 \\
\hline 8 & 13 & & 35 & 32 & 12 & 14 & 18 & 17 & 9 & 19 & 8 \\
\hline 9 & 7 & & 14 & 23 & 6 & 8 & 12 & 11 & 6 & 12 & NS \\
\hline 10 & 2 & & 5 & 6 & 3 & 3 & 4 & 5 & 3 & 4 & 1 \\
\hline 11 & 11 & & 23 & & 23 & & & & 16 & 27 & 8 \\
\hline 12 & 10 & & 34 & & 26 & & & & 19 & 26 & 10 \\
\hline
\end{tabular}

${ }^{\text {a }}$ Poultry litter applied in $\mathrm{Mg} \mathrm{ha}^{-1}$

${ }^{b}$ Composted sludge applied in $\mathrm{Mgha}^{-1}$.

${ }^{\mathrm{c}} \mathrm{LSD}$ at $10 \%$ level from control. 
$240 \%$ of the initial soil P. Poultry litter supplied 74 and $128 \mathrm{~kg} \mathrm{ha}^{-1}$ of P for 3.8 and $7.6 \mathrm{Mg} \mathrm{ha}^{-1}$ rate, respectively. This amount is equivalent to 168 and $291 \mathrm{~kg} \mathrm{ha}^{-1}$ of $\mathrm{P}_{2} \mathrm{O}_{5}$. Fertilizer also increased soil test $\mathrm{P}$ in 6 of 10 sites and the percent increase in soil $P$ from the initial, ranged from 36 to $160 \%$. In cases where both poultry litter and fertilizer increased soil $\mathrm{P}$, fertilizer $\mathrm{P}$ resulted in the smaller increase. This was expected since only $40 \mathrm{~kg} \mathrm{ha}^{-1}$ of $\mathrm{P}_{2} \mathrm{O}_{5}$ was applied. Lower initial soil $\mathrm{P}$ resulted in larger increases in percent soil $\mathrm{P}$ regardless of source. This was expected since most $\mathrm{P}$ adsorption will follow the Langmuir adsorption isotherm at low soil $\mathrm{P}$ concentrations.

\section{CONCLUSIONS}

Poultry litter increased yield in 7 of 13 experiments and of those 7 experiments, 5 had increased yield with poultry litter when fertilizer had no effect. Some of the yield response to litter may have been due to $\mathrm{Ca}$ in the litter. Only two experiments had increased yield due to fertilizer and one of these the yield from poultry litter was greater than the fertilizer treatment. Municipal sludge increased yield in only one site, but only at a high rate. The slow release and low nutrient content makes composted municipal sludge ineffective as a nutrient amendment. There was no conclusive trend in TSMKs with any of the treatments. Low initial soil test $\mathrm{P}$ showed dramatic increases with the application of poultry litter and commercial fertilizer, but increases diminished as initial soil $\mathrm{P}$ increased. Poultry litter produced higher increases in soil $\mathrm{P}$ than fertilizer, but poultry litter treatments applied more total P.

\section{REFERENCES}

1. USDA. National Agricultural Statistic Service Agricultural Statistics; U.S. Government Printing Office: Washington, DC, 2000.

2. Mitchell, C.C.; Donald, J.O. The Value Use of Poultry Manures as Fertilizer; ANR-244 Alabama Coop. Ext. System: Auburn, AL, 1995.

3. Wood, C.W. Broiler litter as a fertilizer: benefits and environmental concerns. Proceedings of National Poultry Waste Management Symposium, Birmingham, AL, Oct 6-8, 1992; Auburn University Printing Service: Auburn, AL, 1992; 304-312.

4. Nyakatawa, E.Z.; Reddy, K.C.; Mays, D.A. Tillage, cover cropping, and poultry litter effects on cotton. II. Growth and yield parameters. Agron. J. 2000, 92, 1000-1007. 
5. Barkenbus, J.N. Overview of the solid waste management situation: federal framework and state initiatives. In Economics of Solid Waste Management in the 90s; Redd, R.C., Pagoulatos, A., Park, W.M., Eds.; Southern Rural Development Center: Mississippi State, MS, 1993; $1-8$.

6. Cummings, B.S. Analysis of Sewage Sludge Treatment and Use/ Disposal Practices of Alabama Treatment Works. M.S. thesis, Auburn University, Auburn, Al, 1995.

7. Raun, W.R.; Johnson, G.V. Crop production and plant soil relationships. In Land Application of Biosolids; Basta, N.T., Ed.; Exp. Stn. B-808; Oklahoma Agric. Exp. Stn.: Stillwater, OK, 1995.

8. McGrath, S.P.; Chaudri, A.M.; Giller, K.E. Long-term effects of metals in sewage sludge on soils, microorganisms and plants. J. Ind. Microbiol. 1995, 14, 94-104.

9. McBride, M.B. Toxic metal accumulation from agricultural use of sludge: are USEPA regulations protective? J. Environ. Qual. 1995, 24, $5-18$.

10. Shaw, R.H. Climate of the United States. In Handbook of Soils and Climate in Agriculture; Kilmer, V.J., Ed.; CRC Press: Boca Raton, FL, 1982; 1-101.

11. Mehlich, A. Determination of $\mathrm{P}, \mathrm{Ca}, \mathrm{Mg}, \mathrm{K}, \mathrm{Na}$ and $\mathrm{NH}_{4}$ by North Carolina Soil Testing Laboratories; Mimeo North Carolina State University: Raleigh, NC, 1953.

12. Hue, N.V.; Evans, C.E. Procedures Used for Soil and Plant Analysis by the Auburn University Soil Testing Laboratory; Dep. Agron. and Soils Series 106; Alabama Agric. Exp. Stn.: Auburn, AL, 1986.

13. SAS Institute. SAS User's Guide: Statistics, 5th Ed.; SAS Institute: Cary, NC, 1985.

14. Hartzog, D.L.; Adams, J.F. Relationship between soil-test P and K and yield response of runner peanuts to fertilizer. Commun. Soil Sci. Plant Anal. 1988, 19, 1645-1653.

15. Adams, F.; Hartzog, D.L. The nature of yield response of Florunner peanuts to lime. Peanut Sci. 1980, 7, 120-123.

16. Hartzog, D.L.; Adams, F. Fertilizer, Gypsum, and Lime Experiments with Peanuts in Alabama; Bull. 448; Alabama Agric. Exp. Stn.: Auburn, AL, 1973.

17. Hartzog, D.L.; Adams, J.F. Soil Fertility Experiments in Alabama, 1973-1986; Bull. 594; Alabama Agric. Exp. Stn.: Auburn, AL, 1988. 